\title{
Factors affecting satisfaction and reuse intention of customers using online motorbike service
}

\author{
Nguyen Thuy Quynh Loan ${ }^{1}$, Ngo Quang Hung ${ }^{1 *}$ \\ ${ }^{1}$ Ho Chi Minh City University of Technology, Vietnam National University HCMC, Vietnam \\ *Corresponding author: ngoquanghung610@gmail.com
}

\begin{tabular}{ll}
\hline \multicolumn{1}{c}{ ARTICLE INFO } & \multicolumn{1}{c}{ ABSTRACT } \\
\hline $\begin{array}{l}\text { DOI:10.46223/HCMCOUJS. } \\
\text { econ.en.8.2.162.2018 }\end{array}$ & $\begin{array}{l}\text { The paper's objective was to identify and measure factors } \\
\text { impacting on satisfaction and reuse intention of customers using } \\
\text { online motorbike service. The research model proposed five } \\
\text { factors affecting customer satisfaction such as perceived service } \\
\text { quality, perceived value, transaction convenience, perceived ease } \\
\text { of use and perceived usefulness as well as two factors affecting } \\
\text { reuse intention such as satisfaction and habit. The study analyzed } \\
\text { data of } 269 \text { suitable questionnaires collected from customers } \\
\text { Revised: July } 8^{\text {th }}, 2018 \\
\text { Accepted: July } 9^{\text {th }}, 2018\end{array}$ \\
$\begin{array}{l}\text { aged 18 and older who have used the online motorbike service in } \\
\text { HCM City. The results indicated that all the five factors affected } \\
\text { customers' satisfaction and that reuse intention was impacted by } \\
\text { motorbike service, online } \\
\text { booking, reuse intention, } \\
\text { satisfaction }\end{array}$ & $\begin{array}{l}\text { satisfaction and habit. The research also proposed managerial } \\
\text { implications for enhancing online motorbike service quality. }\end{array}$ \\
\hline
\end{tabular}

\section{Introduction}

Nowadays, with the development of technology, Internet and smartphone devices, the integration of technology applications into passenger transportation services in Vietnam is no longer something new. Thanks to the development of tracking technology, especially the Global Positioning System (GPS), transportation services using online booking applications are becoming more and more popular. Several companies such as Grab, Uber, Mai Linh and even Go-Jek from Indonesia are offering customers various ride-hailing transport services. These services provide customers with more choices between either a car or a motorbike based on the purpose and the price. A BMG survey of GrabBike Service Analysis (M. T. Nguyen \& Tran, 2016) showed that $77 \%$ of respondents chosea motorbike as the key means of transport because of its convenience, flexibility and cost savings. In Vietnam, motorbikes are also considered the most common means of transportation. Thanks to its cheaper price and convenience, online motorbikes are making a big difference from traditional ones and preferred by most users.

Competition in the online motorbike market among GrabBike, Uber, Mai Linh and other Vietnamese brands has recently become a hot topic and received much attention from themedia and public. However, most previous studies on the online transportation service merely focused on technology adoption (T. D. Nguyen, T. M. Nguyen, \& Huynh, 2015) or on taxi service 
without paying much attention to motorbike service (Isradila \& Indrawati, 2017; Khairani \& Hati, 2016). Therefore, this study aimed to identify and measure the factors affecting satisfaction and reuse the intention of customers sing online motorbike service in Vietnam. Then, the study proposed some managerial implications for companies to enhance online motorbike service quality to meet their customers' demands.

\section{Literature review}

\subsection{Concepts}

Global Positioning System (GPS) is a satellite navigational system, predominantly designed for navigation. GPS uses these "man-made stars" or satellites as reference points to calculate geographical positions, accurate to a matter of meters. A GPS can help us to determine exactly where we are at any given moment (Uddin, Islam, Afjal, \& Nadim, 2013).

Online transportation service is defined as a company that provides customers with a unique service as its core business. These companies use two means for their services: cars for transportation and mobile applications to reserve the trip. Strict competitiveness in this industry made online transportation providers feel the need of maintaining both their service quality and e-service quality. Using this service, customers are easy to switch from one company to their competitors without paying any switching cost on the internet (Barutcu, 2010). According to Jenita (2012), it is defined as a transportation service that all transactions are done through an online base, using smartphones, related applications and the Internet.

Satisfaction is the customer's evaluation of a product or service in terms of whether that product or service has met their needs and expectations (Zeithaml \& Bitner, 2003). According to Kotler and Keller (2006), customer satisfaction is defined as a person's feeling of pleasure or disappointment in the comparison between products' perceived performance to their expectations.

Reuse intention is defined as the individual's judgement about buying again a designated service from the same company, taking into account his or her current situation and likely circumstances (Hellier, Geursen, Carr, \& Rickard, 2003).

\subsection{Factors impacting on customer satisfaction}

\section{Perceived service quality}

Perceived service quality is viewed as the degree and direction of a discrepancy between consumers' perceptions and expectations (Parasuraman, Zeithaml, \& Berry, 1988). In other words, perceived service quality is consumer evaluation of service efficiency that they received and compared with their expectation (Jiang \& Wang, 2006). Previous studies indicated that service quality of providers is a factor that can influence customer satisfaction through their perception of actual experiences after using these services (Sureshchandar, Rajendran, \& Anantharaman, 2002). Murray and Howat (2002) proved that perceived service quality had a positive impact on customer satisfaction in sport and leisure centers. Then, Malik (2012) confirmed the positive relationship between perceived service quality and customer satisfaction in service industries in Pakistan. Thus, hypothesis H1 is suggested as follows: 
H1(+): Perceived service quality positively impacts on customer satisfaction

\section{Perceived value}

Perceived value is consumers' overall assessment of the product or service utility based on perceptions of what is received and what is given (Zeithaml, 1988). Besides, it is defined as consumers' cognitive trade-off between the perceived benefits of the applications and the payment for them (Dodds, Monroe, \& Grewal, 1991). With the growing competition of the market and changes in customer perceptions of products and services, previous researchers have determined that perceived value and customer satisfaction are correlated with each other (Patterson, Johnson, \& Spreng, 1997). The research of Khairani and Hati (2016) in the field of online transportation service also confirmed that perceived value positively influences customer satisfaction. Thus, hypothesis $\mathrm{H} 2$ is suggested as follows:

\section{H2(+): Perceived value positivelyimpacts on customer satisfaction}

\section{Transaction convenience}

Transaction convenience is defined as the customer's perception of the time and effort to make a transaction (Berry, Seiders, \& Grewal, 2002). It is a component of service convenience, it affects consumers when they decide to purchase a service and must complete a transaction for that service. The study of Khazaei, Manjiri, Samiey, and Najafi (2014) in the banking sector has also demonstrated that convenient services which include transaction convenience also have a positive influence on customer satisfaction. Besides, Kin and Farida (2016) argues that transaction convenience has a positive impact on customer satisfaction in online shopping. In motorbike service, more flexible payments through card or cash offer customers more choices and help them to save time. Thus, hypothesis H3 is suggested as follows:

\section{H3(+): Transaction conveniencepositively impacts on customer satisfaction}

\section{Perceived ease of use}

Perceived ease of use is defined as the degree to which a person believes that the use of a particular system would be free of effort (Davis, 1989). In other words, it is the degree to which using technology will provide benefits to consumers in doing certain activities (Venkatesh, Morris, Davis, \& Davis, 2003). Perceived ease of use was also found to have a positive effect on customer satisfaction (Pappas, Pateli, Giannakos, \& Chrissikopoulos, 2014). Thus, hypothesis H4 is suggested as follows:

\section{H4(+): Perceived ease of use positively impacts on customer satisfaction}

\section{Perceived usefulness}

Perceived usefulness is the degree to which a person believes that the use of a particular system would enhance his or her job performance (Davis, 1989; Venkatesh et al., 2003). It is argued that perceived usefulness has a positive influence on customer satisfaction in applying online technology in purchase and transportation services (Isradila \& Indrawati, 2017; Pappas et al., 2014). Thus, hypothesis H5 is suggested as follows: 
H5(+): Perceived usefulness positively impacts on customer satisfaction

\subsection{Factors impacting on reuse intention satisfaction}

There are several studies on the relationship between customer satisfaction and intention. Some previous studies have found that satisfaction is a direct antecedent of behavioral intention (Cronin, Brady, \& Hult, 2000; Dodds et al., 1991; Petrick \& Backman, 2002). Studies of online shopping services also show that satisfaction has a positive influence on customer repurchase intention (Hellier et al., 2003; Pappas et al., 2014; Suhaily \& Soelasih, 2017). In addition, customer satisfaction has also shown a positive influence on reuse intention in the field of airline service (Saha \& Theingi, 2009; Yeoh \& Chan, 2011). Therefore, hypothesis H6 is suggested as follows:

H6(+): Customer satisfaction positively impacts on reuse intention of customers

\section{Habit}

According to Limayem, Hirt, and Cheung (2007), habit is the extent to which people tend to perform behaviors automatically through learning. Habit is equivalent to automatic. If a person's behavior is repeated many times, it becomes habitual and automatically reminds them whenever they intend. In studies of Isradila and Indrawati (2017), and Ngo and Le (2017), habit is the factor directly influencing customer reuse intention. Thus, hypothesis $\mathrm{H} 7$ is suggested as follows:

H7(+): Habit positively impacts on reuse intention of customers

\subsection{Research model}

Based on the above hypotheses, the research model is proposed in Figure 1.

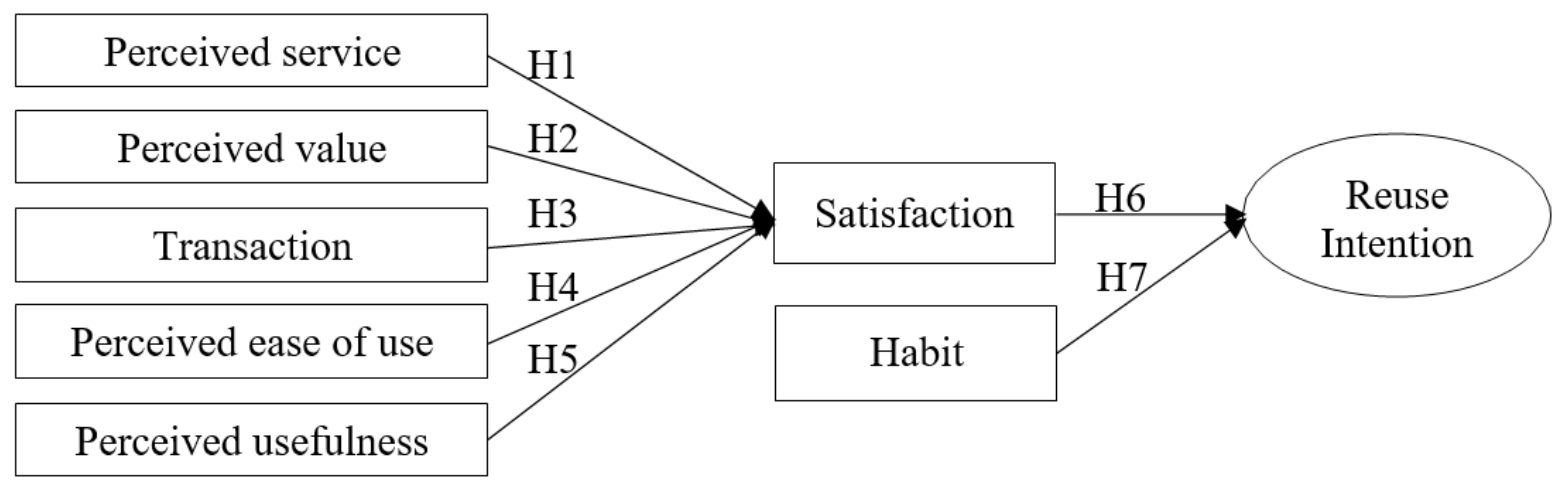

Figure 1. Research model

\section{Research methodology}

The research process consisted of two main steps: preliminary research and formal research. Preliminary research was conducted using qualitative research to correct and supplement the variables suitable for online motorbike service in the Vietnamese context. In this step, the face-to-face discussion was conducted by interviewing 10 people who have used online motorbike service in Ho Chi Minh City. Based on the characteristics and regulations of 
online motorbike service in Vietnam, the interviewees suggested adding twelve variables in the final questionnaire (Table 1). As a result, the number of variables increased from 26 to 38 . In the formal study, a convenient sampling survey using a closed questionnaire was used to collect the data. Revised measurement scales consisted of 38 variables of eight factors (Table 1). The minimum sample size was planned $190(=38 \times 5)$. Then, 269 suitable questionnaires were collected from customers aged 18 and older who have used online motorbike from GrabBike, Uber Moto, Mai Linh Bike in Ho Chi Minh City. Techniques used for data analysis were descriptive statistics, Cronbach's Alpha reliability test, Exploratory Factor Analysis (EFA) and Confirmatory Factor Analysis (CFA) in testing the reliability and validity of the measurement scale, and Structural Equation Modeling (SEM) in testing hypotheses of the research model.

\section{Table 1}

Final measurement scale

\begin{tabular}{|c|c|c|}
\hline Code & Measurement scale & Sources \\
\hline \multicolumn{3}{|c|}{ Perceived service quality } \\
\hline PC01 & Online motorbike service makes me feel safe $(*)$ & \multirow{4}{*}{$\begin{array}{l}\text { Morton, } \\
\text { Anable, and } \\
\text { Caulfield } \\
(2016)\end{array}$} \\
\hline $\mathrm{PC} 02$ & Online motorbike service goes quickly. & \\
\hline PC03 & $\begin{array}{l}\text { The time of picking up and dropping off passengers of online } \\
\text { motorbike service is on schedule. }\end{array}$ & \\
\hline $\mathrm{PC} 04$ & Online motorbike service is available when I have a need. & \\
\hline $\mathrm{PC} 05$ & $\begin{array}{l}\text { The driver compliances with the traffic laws (do not cross the red } \\
\text { lights, take the right lane, wear a helmet). }\end{array}$ & $\begin{array}{l}\text { Qualitative } \\
\text { research }\end{array}$ \\
\hline PC06 & $\begin{array}{l}\text { The attitude and communication of driver with me is enthusiastic } \\
\text { and polite. }(*)\end{array}$ & \\
\hline PC07 & $\begin{array}{l}\text { Transportation (motorbike) and support (helmet, jacket) facilities } \\
\text { are fully equipped. }\end{array}$ & \\
\hline \multicolumn{2}{|c|}{ Perceived value } & \\
\hline PV08 & The price of online motorbike service is suitable. & \multirow{3}{*}{$\begin{array}{l}\text { Dodds et } \\
\text { al. }(1991)\end{array}$} \\
\hline PV09 & $\begin{array}{l}\text { The value of online motorbike service is commensurate with the } \\
\text { amount of money I spend. }(*)\end{array}$ & \\
\hline PV10 & The price of online motorbike service fits my affordability. & \\
\hline PV11 & $\begin{array}{l}\text { The quality of online motorbike service is commensurate with } \\
\text { the amount of money I spend. }\end{array}$ & $\begin{array}{l}\text { Qualitative } \\
\text { research }\end{array}$ \\
\hline \multicolumn{2}{|c|}{ Transaction convenience } & \\
\hline TC12 & The payment method of online motorbike service is simple. & \multirow{2}{*}{$\begin{array}{l}\text { Pham } \\
(2015)\end{array}$} \\
\hline TC13 & The payment method of online motorbike service is quick. & \\
\hline TC14 & $\begin{array}{l}\text { The payment method of online motorbike service is convenient (credit } \\
\text { card, digital wallet or cash...). }\end{array}$ & \\
\hline
\end{tabular}




\begin{tabular}{|c|c|c|}
\hline Code & Measurement scale & Sources \\
\hline TC15 & $\begin{array}{l}\text { I have not encountered any difficulties in interacting with this } \\
\text { service. }(*)\end{array}$ & $\begin{array}{l}\text { Qualitative } \\
\text { research }\end{array}$ \\
\hline \multicolumn{2}{|c|}{ Perceived ease of use } & \\
\hline PE16 & I am easy to book online motorbike service. & \multirow{4}{*}{$\begin{array}{l}\text { Pappas et al. } \\
(2014)\end{array}$} \\
\hline PE17 & Online booking application helps me find a motorbike quickly. & \\
\hline PE18 & $\begin{array}{l}\text { The online booking application tells me the amount payable in } \\
\text { advance. }\end{array}$ & \\
\hline PE19 & I can change the schedule or pick-up/drop-off place easily. $(*)$ & \\
\hline PE20 & It's easy for me to learn how to book online motorbike service & \multirow{2}{*}{$\begin{array}{l}\text { Qualitative } \\
\text { research }\end{array}$} \\
\hline PE21 & The interface of online booking application is simple and easy to use. & \\
\hline \multicolumn{2}{|c|}{ Perceived usefulness } & \\
\hline PU22 & Online motorbike service makes my traveling more convenient. & \multirow{3}{*}{$\begin{array}{l}\text { Pappas et al. } \\
\text { (2014) }\end{array}$} \\
\hline PU23 & Online motorbike service makes my traveling faster. & \\
\hline PU24 & Online motorbike service gives me more options when moving. $\left({ }^{*}\right)$ & \\
\hline PU25 & $\begin{array}{l}\text { Motorbike driver's information shown on the application clearly } \\
\text { helps me feel safe and confident. }\end{array}$ & \multirow[t]{2}{*}{$\begin{array}{l}\text { Qualitative } \\
\text { research }\end{array}$} \\
\hline PU26 & Online booking application helps me save time. & \\
\hline \multicolumn{2}{|l|}{ Habit } & \\
\hline HT27 & I usually use online motorbike service when needed. & \multirow{3}{*}{$\begin{array}{l}\text { Agag and El- } \\
\text { Masry (2016) }\end{array}$} \\
\hline HT28 & I only choose online motorbike service when needed. & \\
\hline HT29 & The use of online motorbike service has become familiar to me. & \\
\hline \multicolumn{2}{|c|}{ Satisfaction } & \\
\hline CS30 & Online motorbike service meets my travel needs. $(*)$ & \multirow{3}{*}{$\begin{array}{l}\text { Pappas et al. } \\
\text { (2014) }\end{array}$} \\
\hline CS31 & Online motorbike service meets my expectation. & \\
\hline CS32 & I feel comfortable using online motorbike service. $\left({ }^{*}\right)$ & \\
\hline CS33 & $\begin{array}{l}\text { The switchboard of online motorbike service often supports and } \\
\text { resolves my troubles fast and exactly. }\end{array}$ & \multirow[t]{2}{*}{$\begin{array}{l}\text { Qualitative } \\
\text { research }\end{array}$} \\
\hline CS34 & $\begin{array}{l}\text { I would advise my friends/relatives/colleagues to use online } \\
\text { motorbike service. }\end{array}$ & \\
\hline \multicolumn{2}{|c|}{ Reuse intention } & \\
\hline
\end{tabular}




\begin{tabular}{|l|l|l|}
\hline Code & \multicolumn{1}{|c|}{ Measurement scale } & Sources \\
\hline RI35 & I will continue to use online motorbike service in the next time. & $\begin{array}{l}\text { Pappas et al. } \\
\text { (2014) }\end{array}$ \\
\cline { 1 - 2 } RI36 & $\begin{array}{l}\text { I will prioritize to use online motorbike service when } \\
\text { choosing vehicles in the city }\end{array}$ & \\
\hline RI37 & I will use online motorbike service more frequently in the future. & $\begin{array}{l}\text { Qualitative } \\
\text { research }\end{array}$ \\
\hline RI38 & I consider myself a loyal customer of online motorbike service. \\
\hline
\end{tabular}

Note: Variables (*) were removed in Cronbach's Alpha reliability analysis and Exploratory Factor Analysis.

Source: The researcher's data analysis

\section{Results and discussions}

\subsection{Descriptive statistics}

The information on survey samples is presented in Table 2.

Table 2

Summary of the sample description

\begin{tabular}{|l|c|c|l|c|c|}
\hline Sample information & Frequency & Percent & Sample information & Frequency & Percent \\
\hline 1. Company & & & 2. Career & & \\
\hline GrabBike & 186 & $45.5 \%$ & Employee & 70 & $26.0 \%$ \\
\hline Uber Moto & 156 & $38.1 \%$ & Student & 8 & $3.0 \%$ \\
\hline Mai Linh Bike & 67 & $16.4 \%$ & Housewife & 34 & $12.6 \%$ \\
\hline Total & 409 & $100 \%$ & Freelancer & 68 & $25.3 \%$ \\
\hline $\begin{array}{l}\text { 3. Time for using } \\
\text { service }\end{array}$ & & & Unskilled labor & 41 & $15.2 \%$ \\
\hline Under 3 months & 38 & $14.1 \%$ & Others & 48 & $17.8 \%$ \\
\hline From 3 to 6 months & 60 & $22.3 \%$ & Total & 269 & $100 \%$ \\
\hline From 6 to 9 months & 59 & $21.9 \%$ & 4. Income & & \\
\hline From 9 to 12 months & 55 & $20.4 \%$ & Under 5 mil. VND & 55 & $20.4 \%$ \\
\hline Over 12 months & 57 & $21.2 \%$ & From 5 to 10 mil VND & 78 & $29.0 \%$ \\
\hline Total & 269 & $100 \%$ & From 11 to 20 mil VND & 71 & $26.4 \%$ \\
\hline 5. Gender & 115 & $42.8 \%$ & Total & 65 & $24.2 \%$ \\
\hline Male & 154 & $57.2 \%$ & & 269 & $100 \%$ \\
\hline Female & 269 & $100 \%$ & & & \\
\hline Total & & & Over 20 mil VND & & \\
\hline
\end{tabular}




\begin{tabular}{|l|c|l|l|l|l|}
\hline Sample information & Frequency & Percent & Sample information & Frequency & Percent \\
\hline 6. Age & & & & & \\
\hline $18-29$ years old & 109 & $40.5 \%$ & & & \\
\hline $30-39$ years old & 88 & $32.7 \%$ & & & \\
\hline $40-49$ years old & 72 & $26.8 \%$ & & & \\
\hline Total & 269 & $100 \%$ & & & \\
\hline
\end{tabular}

Source: The researcher's data analysis

\subsection{Cronbach's Alpha and Exploratory Factor Analysis (EFA)}

Cronbach's Alpha reliability analysis measured the internal consistency of the constructed items to assess the reliability of each factor in measurement scales. The results of the Cronbach's Alpha reliability test showed that 35 variables were retained and 3 variables were eliminated (Table 1) as PC06, PV09 and CS32 because their corrected item-total correlation was less than 0.3 . The reliabilities of the measurement scales after deleting all three variables have Cronbach's Alpha coefficients of 0.816 to 0.913 , which were greater than 0.8 (Table 3). Therefore, the measurement scales are reliable.

EFA was used to test the validity of measurement scales by using Principal Axis Factoring and Promax rotations. Five variables were eliminated as PE19, PU24, TC15, CS30 and PC01 (Table 1) because their factor loading coefficients were less than 0.5. The KMO $(0.838>0.5)$ and Bartlett's test $(\mathrm{p}<0.05)$ were satisfactory to confirm the appropriateness to use factor analysis. The total variance extracted of $69.3 \%$ (> 50\%) was satisfactory for retention based on the total variance criterion (Table 3). The variables on the same factor had a high factor loading coefficients (> 0.5) so that the measurement scales were convergent. In addition, eight factors were extracted in accordance with the original eight concepts and they all were discriminated. Thus, the measurement scales were valid. Cronbach's Alpha reliability test and the final EFA are presented in Table 3. As a result, 30 variables of eight factors will be used for CFA in the next step.

\section{Table 3}

Cronbach's Alpha and the final EFA

\begin{tabular}{|l|l|l|l|c|c|l|l|l|}
\hline & $\begin{array}{r}\text { Perceived } \\
\text { ease of use }\end{array}$ & $\begin{array}{c}\text { Perceived } \\
\text { usefulness }\end{array}$ & $\begin{array}{r}\text { Reuse } \\
\text { intention }\end{array}$ & $\begin{array}{c}\text { Perceived } \\
\text { quality }\end{array}$ & $\begin{array}{c}\text { Perceived } \\
\text { value }\end{array}$ & $\begin{array}{c}\text { Transaction } \\
\text { convenience }\end{array}$ & Habit & $\begin{array}{c}\text { Satisfac- } \\
\text { tion }\end{array}$ \\
\hline PC02 & & & & 0.771 & & & & \\
\hline PC03 & & & & 0.721 & & & & \\
\hline PC04 & & & & 0.761 & & & & \\
\hline PC05 & & & & 0.696 & & & & \\
\hline PC07 & & & & 0.693 & & & & \\
\hline
\end{tabular}




\begin{tabular}{|c|c|c|c|c|c|c|c|c|}
\hline & $\begin{array}{r}\text { Perceived } \\
\text { ease of use }\end{array}$ & $\begin{array}{c}\text { Perceived } \\
\text { usefulness }\end{array}$ & $\begin{array}{c}\text { Reuse } \\
\text { intention }\end{array}$ & $\begin{array}{c}\text { Perceived } \\
\text { quality }\end{array}$ & $\begin{array}{c}\text { Perceived } \\
\text { value }\end{array}$ & $\begin{array}{l}\text { Transaction } \\
\text { convenience }\end{array}$ & Habit & $\begin{array}{c}\text { Satisfac- } \\
\text { tion }\end{array}$ \\
\hline PV08 & & & & & 0.831 & & & \\
\hline PV10 & & & & & 0.940 & & & \\
\hline PV11 & & & & & 0.866 & & & \\
\hline $\mathrm{TC} 12$ & & & & & & 0.831 & & \\
\hline TC13 & & & & & & 0.921 & & \\
\hline TC14 & & & & & & 0.849 & & \\
\hline PE16 & 0.733 & & & & & & & \\
\hline PE17 & 0.793 & & & & & & & \\
\hline PE18 & 0.822 & & & & & & & \\
\hline PE20 & 0.888 & & & & & & & \\
\hline PE21 & 0.879 & & & & & & & \\
\hline PU22 & & 0.806 & & & & & & \\
\hline PU23 & & 0.865 & & & & & & \\
\hline PU25 & & 0.757 & & & & & & \\
\hline PU26 & & 0.917 & & & & & & \\
\hline HT27 & & & & & & & 0.814 & \\
\hline HT28 & & & & & & & 0.774 & \\
\hline HT29 & & & & & & & 0.816 & \\
\hline CS31 & & & & & & & & 0.831 \\
\hline CS33 & & & & & & & & 0.728 \\
\hline CS34 & & & & & & & & 0.788 \\
\hline IR35 & & & 0.860 & & & & & \\
\hline IR36 & & & 0.836 & & & & & \\
\hline IR37 & & & 0.794 & & & & & \\
\hline IR38 & & & 0.825 & & & & & \\
\hline $\begin{array}{l}\text { Cronbac } \\
\text { h's } \\
\text { Alpha }\end{array}$ & 0.885 & 0.859 & 0.898 & 0.821 & 0.913 & 0.816 & 0.844 & 0.879 \\
\hline $\begin{array}{l}\text { Eigenvalu } \\
\mathrm{e}\end{array}$ & 7.855 & 3.253 & 2.862 & 2.758 & 2.376 & 1.642 & 1.417 & 1.003 \\
\hline
\end{tabular}

Source: The researcher's data analysis 


\subsection{Confirmatory Factor Analysis (CFA)}

The CFA was used to confirm the factor structure extracted in the EFA. The CFA was performed using the Maximum Likelihood Estimate (MLE) method, which is a very commonly used method (Hair, Black, Babin, \& Anderson, 2014). The results of CFA are presented in Table 4 and Figure 2.

Table 4

Goodness-of-Fit Indices - CFA measurement model

\begin{tabular}{|l|c|c|c|c|c|}
\hline \multicolumn{1}{|c|}{ Criteria } & CMIN/DF & GFI & TLI & CFI & RMSEA \\
\hline Threshold & $<3$ & $\begin{array}{c}>0.9 \\
(>0.8 \text { permissible })\end{array}$ & $>0.9$ & $>0.9$ & $<0.08$ \\
\hline Actual value & 1.767 & 0.861 & 0.937 & 0.945 & 0.053 \\
\hline
\end{tabular}

Source: The researcher's data analysis

The Goodness of Fit Indices (GFI) were less than 0.9, however, according to D. T. Nguyen and T. M. T. Nguyen (2011), if a model has TLI and CFI values from 0.9 to 1, CMIN I df less than 3, and RMSEA smaller or equal 0.08 , it is still permissible. Therefore, it is concluded that the GFI for the proposed model indicated the overall model fits.

\section{Testing validity and reliability in the CFA}

It is absolutely necessary to establish convergent and discriminant validity, as well as reliability, when doing a CFA. There are a few measures that are useful for establishing validity and reliability (Hair et al., 2014) as Composite Reliability (CR) and Average Variance Extracted (AVE).

In the $\mathrm{CFA}, \mathrm{CR}$ values were $0.747 \div 0.914$ higher than 0.5 , so all measurement scales achieve reliability. Because AVE values were $0.528 \div 0.783$ greater than 0.5 and all variables have a standardized regression weight of 0.665 to 0.933 which was greater than 0.5 and statistically significant $(\mathrm{p}<0.05)$, the scales get convergent validity. The scales also get discriminant validity because of the square root of AVE greater than inter-construct correlations. Thus, it is concluded that the CFA measurement model achieves reliability and validity. 


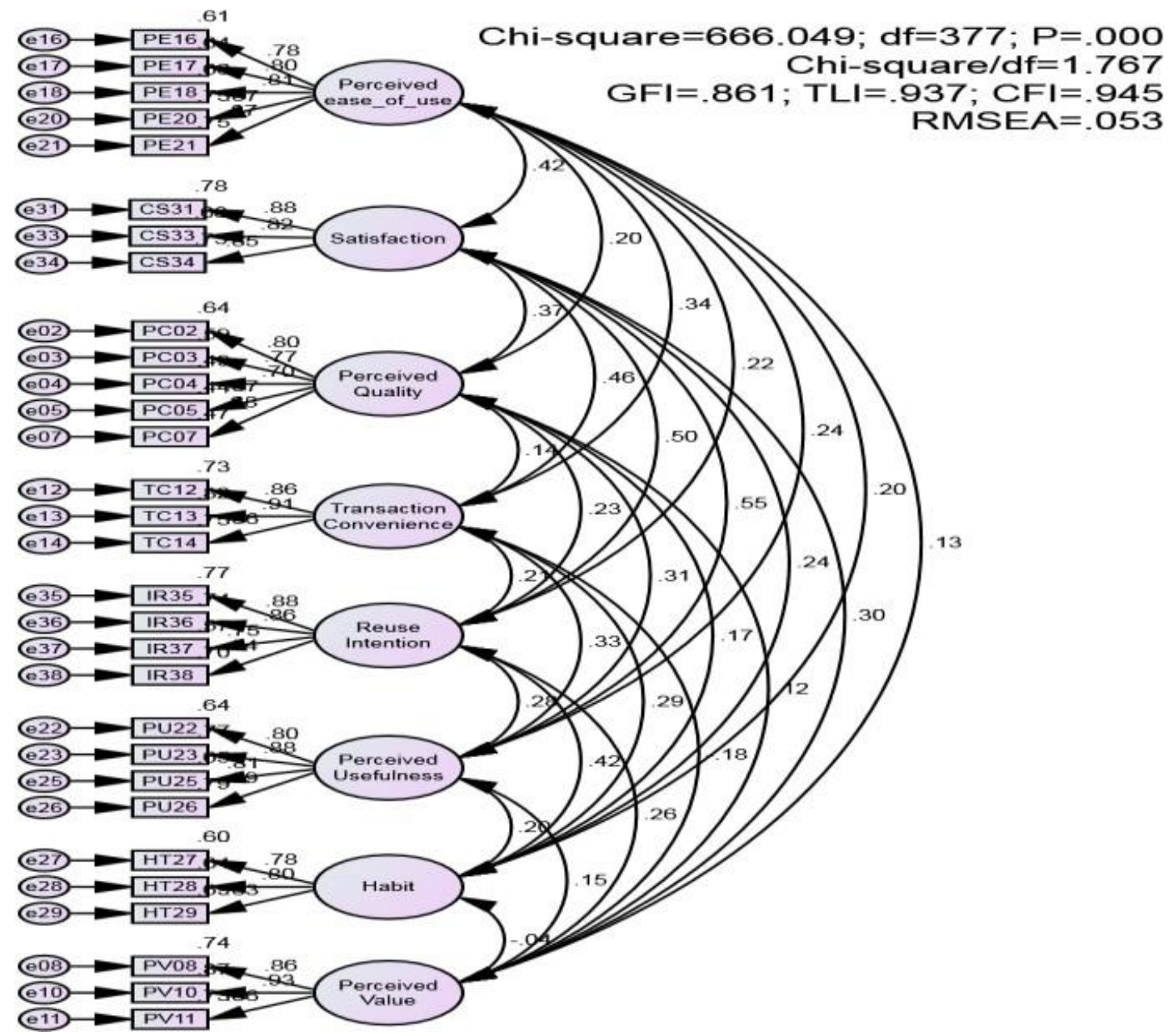

Figure 2. CFA measurement model

\subsection{Structural Equation Modeling (SEM)}

The results of SEM are presented in Table 5 and Figure 3. The Goodness of Fit Indices for the proposed model indicated the overall model fits.

\section{Table 5}

Goodness-of-Fit indices - SEM structural model

\begin{tabular}{|l|c|c|c|c|c|}
\hline \multicolumn{1}{|c|}{ Criteria } & CMIN/DF & GFI & TLI & CFI & RMSEA \\
\hline Threshold & $<3$ & $\begin{array}{c}>0.9 \\
(>0.8 \text { permissible })\end{array}$ & $>0.9$ & $>0.9$ & $<0.08$ \\
\hline Actual value & 1.805 & 0.855 & 0.934 & 0.941 & 0.055 \\
\hline
\end{tabular}

Source: The researcher's data analysis 


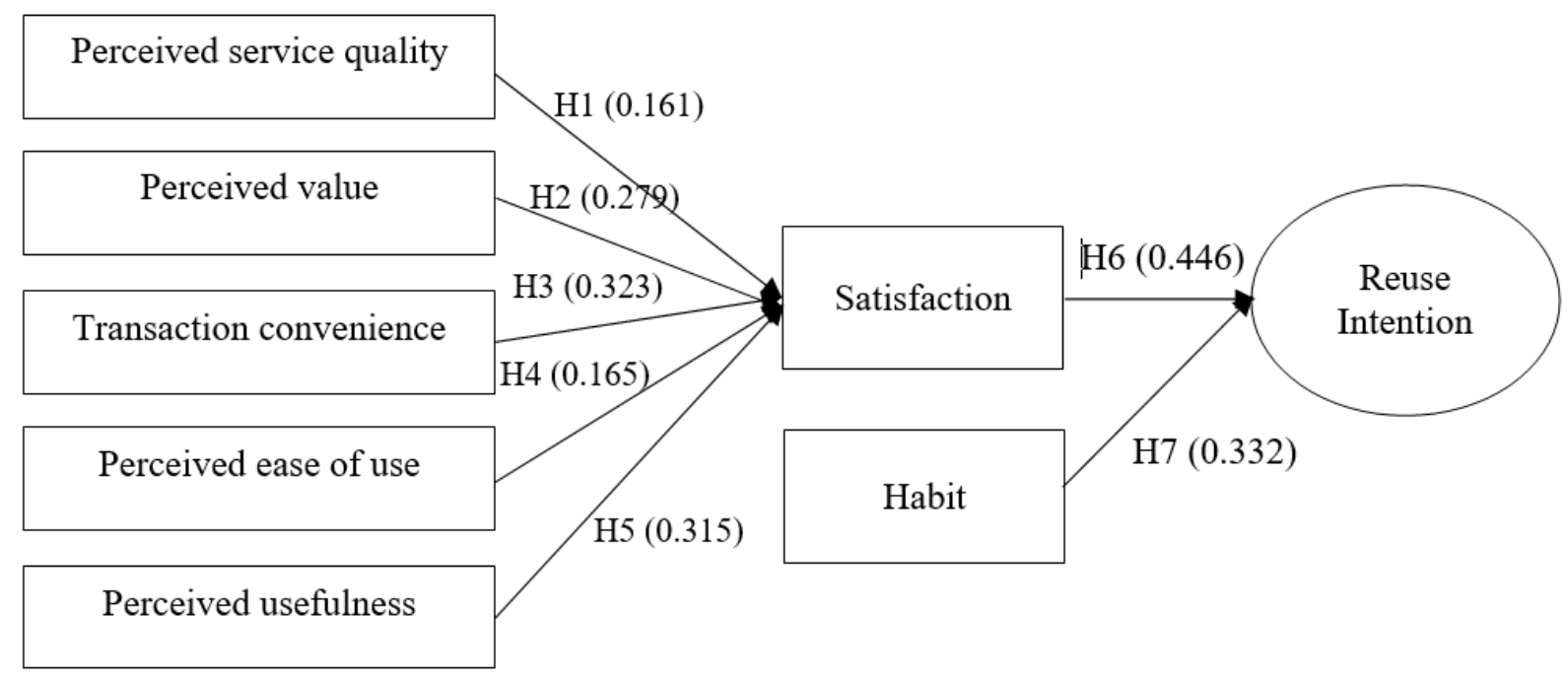

Figure 3. Research model and hypothesis testing results

\section{Hypothesis testing}

\section{Table 6}

The results of hypothesis testing

\begin{tabular}{|l|l|l|l|}
\hline \multicolumn{1}{|c|}{ Relationship } & $\begin{array}{c}\text { Standardized } \\
\text { Regression } \\
\text { Weights }\end{array}$ & P & Comment \\
\hline Perceived service quality $\rightarrow$ Satisfaction & 0.161 & 0.024 & Support H1 \\
\hline Perceived value $\rightarrow$ Satisfaction & 0.279 & 0.001 & Support H2 \\
\hline Transaction convenience $\rightarrow$ Satisfaction & 0.323 & 0.002 & Support H3 \\
\hline Perceived ease of use $\rightarrow$ Satisfaction & 0.165 & 0.033 & Support H4 \\
\hline Perceived usefulness $\rightarrow$ Satisfaction & 0.315 & 0.002 & Support H5 \\
\hline Satisfaction $\rightarrow$ Reuse intention & 0.446 & 0.002 & Support H6 \\
\hline Habit $\rightarrow$ Reuse intention & 0.332 & 0.001 & Support H7 \\
\hline
\end{tabular}

Source: Data analysis result of the research

\section{Model testing by Bootstrap method}

To ensure that the results from SEM can be generalized to the whole population, the Bootstrap technique is used with $\mathrm{N}=1000$. All relationships are statistically significant. Consequently, it is concluded that the SEM structure model is reliable and can be generalized.

\subsection{Discussion}

The results showed that all seven hypotheses were supported. Here is the discussion for each hypothesis:

Transaction convenience $(\beta=0.323)$ is the most positive factor influencing customer 
satisfaction (H3). The online motorbike service now provides customers with convenient, safe and fast payment methods. Besides paying by cash, customers can pay by card or electronic wallet. Although these payment methods are becoming popular and compatible with the cash replacement strategy implemented by many countries, it's not easy for Vietnamese to use such methods instead of cash payment at the moment. However, this service will be popular for customers in Vietnam in the near future.

Perceived usefulness $(\beta=0.315)$ is the second most positive factor influencing customer satisfaction (H5). Customers only use a new service if they perceive the benefits brought about by such service. For online motorbike service, the benefits not only lie on the travel but also on other additional values such as clear driver and vehicle information, and time-saving booking.

Perceived value $(\beta=0.279)$ is the next positive factor affecting customer satisfaction (H2). Consumers are always looking for a more affordable and competitive price in choosing transportation services. And when the value of online motorbike service meets customers' expectations, their satisfaction will increase.

Perceived ease of use $(\beta=0.165)$ is also a positive factor affecting Customer satisfaction (H4). This shows that it is easy for customers to learn the usage of the online booking application.

Perceived service quality ( $\beta=0.161)$ has an impact on customer Satisfaction (H1). The more serious the traffic jams in the city are, the more popular the online motorbike service becomes. Factors such as fast, on-time, legal and comfortable vehicles can contribute to customer perception of better service quality.

Testing results also show that reuse intention was impacted by customer satisfaction ( $\beta$ $=0.446)(\mathrm{H} 6)$ and habit $(\beta=0.332)(\mathrm{H} 7)$. The impact of Satisfaction is greater than Habits, which means the more customers are satisfied with the service, the more likely they will reuse it.

In comparison with previous studies on online transportation services by Khairani and Hati (2016), and Isradila and Indrawati (2017), this study focuses on online motorbike service instead of an online taxi (four-wheeled vehicles). This study is different from previous research in terms of research object in the context that online motorbike services have gradually become more popular in Vietnam's big cities. The results of this study are similar to those of the two previous studies. However, this study adds a transaction convenience factor and tests whether it has the greatest impact on customer satisfaction. This factor also indirectly affects the reuse intention of customers using online motorbike service.

\section{Conclusion}

Online motorbike is becoming more and more popular in Vietnam besides online taxi. It offers a variety of transportation options for people to meet their travel needs and save their time and money. There are many factors that affect customer satisfaction and reuse intention. The findings of this study show that five factors affecting the satisfaction of customers using online motorbike services in the descending order are transaction convenience, perceived 
usefulness, perceived value, perceived ease of use and perceived service quality. Reuse intention is influenced by satisfaction and habits. The study then proposes some managerial implications to increase customer satisfaction and thereby increase the intention to reuse the online motorbike service:

Transaction convenience: Payment via card or electronic wallet is increasingly popular in many developed countries. However, based on the current situation in Vietnam, companies had better maintain cash payment and combine ATM card or Member card for this method. Besides, businesses must improve their network quality and security to make customer's online transactions safe, convenient and fast.

Perceived usefulness: Companies need to focus on information frequently searched by customers and displayed on the application to update and improve the booking application. If customers' thoughts and demands are met, companies can set accurate, timely targets and action plans to better serve the customers.

Perceived value: Special attention should be paid to the development of price strategy because it is a very important factor in this competitive service industry. Companies should also launch promotions, membership discounts or discount codes to increase the satisfaction of loyal customers and encourage the experience of potential customers.

Perceived ease of use: Advantages and disadvantages of online booking for customers should also be taken into account to design a process suitable to the majority of users including old customers not well versed in online technology. Therefore, simple and visual interface design will help customers easier in using the online booking service.

Perceived service quality: Companies need to improve the service quality of online motorbike by organizing training courses on communication and customer handling skills for drivers, supervising drivers' compliance with traffic laws and their use of company uniform while on duty, checking the safety of motorbikes, and quickly and satisfactorily receiving and handling customers' complaints. Besides, they also need to listen to customers' feedbacks about drivers' attitudes, behaviors and service quality to draw valuable lessons, overcome limitations and promote service benefits.

Although the study has achieved certain results, there are still some limitations. First, a generalization of the results is not high due to the convenient sampling method. Second, data collection process occurred before the official acquisition of Grab over Uber's operations in Southeast Asia. The merger of these two transportation services giants might have a significant impact on the competitiveness of domestic transportation companies and, above all, on customer satisfaction and reuse intention when offers and discounts are cut off to self-determination of the service price. Therefore, further research is needed after this acquisition.

\section{References}

Agag, G., \& El-Masry, A. A. (2016). Understanding the determinants of hotel booking intentions and moderating role of habit. International Journal of Hospitality Management, 54, 52-67. doi:10.1016/j.ijhm.2016.01.007 
Barutcu, S. (2010). E-customer satisfaction in the e-tailing industry: An empirical survey for Turkish e-customers. Ege Academic Review, 10(1), 15-35. doi:10.21121/eab.2010119646

Berry, L. L., Seiders, K., \& Grewal, D. (2002). Understanding service convenience. Journal of Marketing, 66(3), 1-17. doi:10.1509/jmkg.66.3.1.18505

Cronin, J. J., Jr., Brady, M. K., \& Hult, G. T. M. (2000). Assessing the effects of quality, value, and customer satisfaction on consumer behavioral intentions in service environments. Journal of Retailing, 76(2), 193-218. doi:10.1016/S0022-4359(00)00028-2

Davis, F. D. (1989). Perceived usefulness, perceived ease of use, and user acceptance of information technology. MIS Quarterly, 13(3), 319-340. doi:10.2307/249008

Dodds, W. B., Monroe, K. B., \& Grewal, D. (1991). Effects of price, brand, and store information on buyers' product evaluations. Journal of Marketing Research, 28(3), 307319. doi: $10.2307 / 3172866$

Hair, J. F., Black, W., Babin, B. J., \& Anderson, R. E. (2014). Multivariate data analysis: A global perspective (7th ed.). New Jersey, NJ: Pearson Prentice Hall.

Hellier, P. K., Geursen, G. M., Carr, R. A., \& Rickard, J. A. (2003). Customer repurchase intention: A general structural equation model. European Journal of Marketing, 37(11), 1762-1800. doi:10.1108/03090560310495456

Isradila, \& Indrawati, R. M. (2017). Analysis of user acceptance towards online transportation technology using UTAUT 2 model: A case study in Uber, Grab and Go-Jek in Indonesia. International Journal of Science and Research, 6(7), 2319-7064. doi:10.21275/art20175426

Jenita (2012). Transportasi Online. Retrieved March 11, 2018, from https://prezi.com/hqywaio5gn1k/transportasi-online/

Jiang, Y., \& Wang, C. L. (2006). The impact of effect on service quality and satisfaction: The moderation of service contexts. Journal of Services Marketing, 20(4), 211-218. doi:10.1108/08876040610674562

Khairani, I., \& Hati, S. (2016). The effects of perceived service quality towards customer satisfaction and behavioral intentions in online transportation. International Journal of Humanities and Management Sciences (IJHMS), 5(1), 7-11.

Khazaei, A., Manjiri, H., Samiey, E., \& Najafi, H. (2014). The effect of service convenience on customer satisfaction and behavioral responses in bank industry. International Journal of Basic Sciences \& Applied Research, 3(1), 16-23.

Kin, N., \& Farida, N. (2016). Effects of convenience online shopping and satisfaction on repeatpurchase intention among students of higher institutions in Indonesia. Journal of Internet Banking and Commerce, 21(2), 1-19.

Kotler, P., \& Keller, K. (2006). Marketing Management (12th ed.). New Jersey, NJ: Pearson Prentice-Hall. 
Limayem, M., Hirt, S. G., \& Cheung, C. M. K. (2007). How habit limits the predictive power of intention: The case of information systems continuance. MIS Quarterly, 31(4), 705737. doi: $10.2307 / 25148817$

Malik, S. U. (2012). Customer satisfaction, perceived service quality and mediating role of perceived value. International Journal of Marketing Studies, 4(1), 68-76. doi:10.5539/ijms.v4n1p68

Morton, C., Anable, L. J., \& Caulfield, B. (2016). Customer perceptions of quality of service in public transport: Evidence for bus transit in Scotland. Case Studies on Transport Policy, 4(3), 199-207. doi:10.1016/j.cstp.2016.03.002

Murray, D., \& Howat, G. (2002). The relationships among service quality, value, satisfaction, and future intentions of customers at an Australian Sports and Leisure Centre. Sport Management Review, 5(1), 25-43. doi:10.1016/S1441-3523(02)70060-0

Ngo, M. T., \& Le, T. H. V. (2017). An analysis of factors affecting the customers' repurchase of line transportation in Can Tho City. Scientific Journal of Can Tho University, 50, 3444.

Nguyen, D. T., \& Nguyen, T. M. T. (2011). Marketing research: Application of Structural Equation Modeling (SEM). Ho Chi Minh City, HCMC: Labor Publishing House.

Nguyen, M. T., \& Tran, H. M. P. (2016). Analysis GrabBike service. Ho Chi Minh City, Vietnam: BMG International Education.

Nguyen, T. D., Nguyen, T. M., \& Huynh, C. T. M. (2015). Technology adoption: A study about Uber taxi service. Journal of Science and Technology Development, 18(4), 84-93. doi:10.32508/stdj.v18i4.973

Pappas, I., Pateli, A., Giannakos, M., \& Chrissikopoulos, V. (2014). Moderating effects of online shopping experience on customer satisfaction and repurchase intentions. International Journal of Retail \& Distribution Management, 42(3), 187-204. doi:10.1108/IJRDM-03-2012-0034

Parasuraman, A. P., Zeithaml, V. A., \& Berry, L. L. (1988). SERVQUAL: A multiple-item scale for measuring consumer perceptions of service quality. Journal of Retailing, 64(1), $12-40$.

Patterson, P. G., Johnson, L. W., \& Spreng, R. A. (1997). Modeling the determinants of customer satisfaction for business-to-business professional services. Journal of the Academy of Marketing Science, 25(1), 4-17. doi:10.1007/BF02894505

Petrick, J. F., \& Backman, S. J. (2002). An examination of the construct of perceived value for the prediction of golf travelers' intention to revisit. Journal of Travel Research, 41(1), 38-45. doi:10.1177/004728750204100106

Pham, H. P. T. (2015). The impact of convenience in online shopping on consumer intentions. Ho Chi Minh City, Vietnam: Ho Chi Minh City University of Technology, VNU HCMC. 
Saha, G. C., \& Theingi (2009). Service quality, satisfaction, and behavioral intentions: A study of low-cost airline carriers in Thailand. Managing Service Quality: An International Journal, 19(3), 350-372. doi:10.1108/09604520910955348

Suhaily, L., \& Soelasih, Y. (2017). What effects repurchase intention of online shopping? International Business Research, 10(12), 113-122. doi:10.5539/ibr.v10n12p113

Sureshchandar, G. S., Rajendran, C., \& Anantharaman, R. N. (2002). The relationship between service quality and customer satisfaction - A factor specific approach. Journal of Services Marketing, 16(4), 363-379. doi:10.1108/08876040210433248

Uddin, P., Islam, Z., Afjal, M. I., \& Nadim (2013). GPS-based location tracking system via android device. International Journal of Research in Computer Engineering and Electronics, 2(5), 1-7.

Venkatesh, V., Morris, M. G., Davis, G. B., \& Davis, F. D. (2003). User acceptance of information technology: Toward a unified view. MIS Quarterly, 27(3), 425-478. doi: $10.2307 / 30036540$

Yeoh, E., \& Chan, J. K. L. (2011). Malaysian low cost airlines: Key influencing factors on customers' repeat purchase intention. World Applied Sciences Journal, 12, 35-43.

Zeithaml, V. A. (1988). Consumer perceptions of price, quality, and value: A means-end model and synthesis of evidence. Journal of Marketing, 52(3), 2-22. doi:10.2307/1251446

Zeithaml, V. A., \& Bitner, M. J. (2003). Services marketing integrating customer focus across the firm (3rd ed.). New York, NY: Irwin McGraw-Hill. 